\title{
Koncepcja kompetencyjno-finansowego podziału zadań jednostki samorządu terytorialnego
}

\begin{abstract}
Anna Strzelczak*
Celem artykulu jest prezentacja koncepcji kompetencyjno-finansowego podziału zadań jednostki samorzadu terytorialnego na: rzadowe, samorzadowo-rzadowe $i$ samorzadowe. Koncepcja zostata opracowana na bazie krytycznej oceny zasady adekwatności środków do zadań wtasnych, zleconych i porozumieniowych. Dane źródtowe do analizy adekwatności zadaniowo-finansowej stanowity dane budżetowe pochodzace ze sprawozdan $z$ wykonania budżetów miast na prawach powiatu Szczecina oraz Krakowa i Poznania. Z uwagi na dostęp do sprawozdań analiza objęto lata 2011-2013.
\end{abstract}

Słowa kluczowe: podział zadań JST, koncepcja korekcyjno-kompensacyjna, dofinasowanie zadań rządowych.

Nadesłany: 06.03.17 | Zaakceptowany do druku: 28.12.17

\section{The concept of competence and financial division tasks of the local government unit}

The aim of the article is to present the concept of competence and financial division of tasks of the local government unit into: governmental, local-governmental, and local community. The concept has been developed on the basis of a critical assessment of the adequacy of funds for own, commissioned and agreement tasks. The source data for the task-and-financial adequacy analysis were based in budget data from reports on the implementation of city budgets, being on the poviat rights like Szczecin, Kraków and Poznań. Due to access to reports, the analysis covered the years 2011-2013.

Keywords: division of tasks of the local government unit, corrective and compensatory conception, co-financing of government tasks.

Submitted: 06.03.17 | Accepted: 28.12.17

JEL: F15, G32

\footnotetext{
* Anna Strzelczak, mgr, doktorantka - Uniwersytet Szczeciński, Wydział Nauk Ekonomicznych i Zarządzania.

Adres do korespondencji: Uniwersytet Szczeciński, Wydział Nauk Ekonomicznych i Zarządzania, ul. Mickiewicza 64, 71-101 Szczecin.
} 


\section{Wstęp}

Celem artykułu jest prezentacja koncepcji kompetencyjno-finansowego podziału zadań jednostki samorzadu terytorialnego. Dotychczasowe kryteria podziału zadań jednostek samorząu terytorialnego są zgodne $\mathrm{z}$ ustawami kompetencyjnymi. Wyróżnia się więc zadania publiczne własne, zlecone i porozumieniowe. Niniejszy podział zadań jednostek samorządu terytorialnego utrudnia ocenę adekwatności środków przeznaczonych na poszczególne rodzaje zadań.

Biorąc pod uwage kompetencje oraz źródła finansowania, w artykule zaprezentowano koncepcję kompetencyjno-finansowego podziału zadań na: rządowe, samorządowo-rządowe i samorządowe.

Koncepcja została opracowana na bazie krytycznej oceny zasady adekwatności środków do zadań własnych, zleconych i porozumieniowych. Dane źródłowe do analizy adekwatności zadaniowo-finansowej stanowiły dane budżetowe pochodzące ze sprawozdań z wykonania budżetów miast na prawach powiatu Szczecina oraz Krakowa i Poznania.

Do artykułu dołączono przykład wykorzystania koncepcji kompetencyjno-finansowego podziału zadań na bazie wieloletniego programu „Pomoc państwa w zakresie dożywiania" jako zadania samorządowo-rządowego w latach 2011-2013. Rada Ministrów uchwała nr 221 z dnia 10 grudnia 2013 r. ustanowiła wieloletni program wspierania finansowego gmin w zakresie dożywiania „Pomoc państwa w zakresie dożywiania" na lata 2014-20201. Na podstawie nowych założeń monitoringu programu Rada Ministrów nie przyjmuje rocznego sprawozdania $\mathrm{z}$ realizacji Programu za poprzedni rok budżetowy $\mathrm{w}$ formie uchwały, co wiąże się z brakiem jego publikacji na stronach ministerstwa właściwego do spraw zabezpieczenia społecz- nego. Z uwagi na dostęp do sprawozdań analizą objęto lata 2011-2013.

\section{Wprowadzenie do podziału zadań jednostek samorządu terytorialnego według ustaw kompetencyjnych i źródeł finansowania}

$\mathrm{Na}$ podstawie ustaw kompetencyjnych (ustawa o samorządzie gminnym, powiatowym i wojewódzkim) zakres działania samorządów zdefiniowany jest poprzez następujące zadania publiczne:

- własne dla: gmin o znaczeniu lokalnych, powiatów - o charakterze ponadgminnym, województwa - o charakterze wojewódzkim,

- zlecone: zapewniające wykonywanie określonych w ustawach zadań i kompetencji kierowników powiatowych służb, inspekcji i straży, zlecone $\mathrm{z}$ zakresu administracji rządowej, z zakresu organizacji przygotowań i przeprowadzenia wyborów powszechnych i referendów,

- porozumieniowe: $z$ zakresu administracji rządowej na podstawie porozumień $\mathrm{z}$ organami tej administracji, z zakresu właściwości innych jednostek samorządu terytorialnego na podstawie porozumień $\mathrm{z}$ tymi jednostkami.

Szczegółowy podział zadań publicznych w odniesieniu do poszczególnych szczebli samorzadu terytorialnego przedstawiono w tabeli 1 . Jak wynika $\mathrm{z}$ danych przedstawionych $\mathrm{w}$ tabeli, istnieją kompetencje i zadania wspólne dla gmin, powiatów czy województw. Dodatkowo ustawodawca utworzył 46 miast (gmin) na prawach powiatu (określanych jako powiaty miejskie) realizujące jednocześnie kompetencje i zadania w zakresie gminy i powiatu.

Zestawienie zadań publicznych według kryterium ustawowego i źródeł finansowania zaprezentowano w tabeli 2. 
Tabela 1. Podział zadań jednostki samorządu terytorialnego - wg ustaw samorządowych i kompetencji

\begin{tabular}{|c|c|c|c|c|c|c|c|}
\hline \multirow{2}{*}{ Lp. } & \multirow{2}{*}{ Zakres działania } & \multicolumn{6}{|c|}{ Zadania publiczne } \\
\hline & & Gmina & przypis ustawy ${ }^{1}$ & Powiat & \begin{tabular}{l|l} 
przypis ustawy ${ }^{2}$ \\
\end{tabular} & Województwo & przypis ustawy $^{3}$ \\
\hline I. & ZADANIA WŁASNE & & art. 7 ust. 1 & & art. 4 ust. 1 & & art. 14 ust. 1 \\
\hline \multirow[t]{23}{*}{1.} & $\begin{array}{l}\text { Gmina - o znaczeniu lokalnym, Powiat - o charakterze ponadgminnym, } \\
\text { Województwo - o charakterze wojewódzkim }\end{array}$ & & & & & & \\
\hline & 1. - administracja architektoniczno-budowlana & & & $\mathrm{x}$ & pkt 11) & & \\
\hline & 2. - bezpieczeństwo publiczne & & & & & $\mathrm{X}$ & pkt 14) \\
\hline & 3. - biblioteki gminne i instytucje kultury & $\mathrm{x}$ & pkt 9) & & & & \\
\hline & 4. - cmentarze gminne & $\mathrm{X}$ & pkt 13) & & & & \\
\hline & 5. - działalność w zakresie telekomunikacji & $\mathrm{X}$ & pkt 3a) & $\mathrm{X}$ & pkt 23) & $\mathrm{X}$ & pkt 15a) \\
\hline & 6. - edukacja publiczna & $\mathrm{X}$ & pkt 8) & $\mathrm{x}$ & pkt 1) & $\mathrm{x}$ & pkt 1) \\
\hline & 7. - geodezja, kartografia i kataster & & & $\mathrm{x}$ & pkt 9) & & \\
\hline & 8. - gminne budownictwo mieszkaniowe & $\mathrm{x}$ & pkt 7) & & & & \\
\hline & 9. - gminne drogi, ulice, mosty, place oraz organizacja ruchu drogowego & $\mathrm{X}$ & pkt 2) & & & & \\
\hline & 10. - gospodarka nieruchomościami & $\mathrm{X}$ & pkt 1) & $\mathrm{x}$ & pkt 10) & & \\
\hline & 11. - gospodarka wodna & $\mathrm{X}$ & pkt 1) & $\mathrm{x}$ & pkt 12) & $\mathrm{X}$ & pkt 9) \\
\hline & 12. - kultura fizyczna i turystyka & $\mathrm{X}$ & pkt 10) & $\mathrm{X}$ & pkt 8) & $\mathrm{X}$ & pkt 11) \\
\hline & 13. - kultura oraz ochrona zabytków i opieka nad zabytkami & $\mathrm{x}$ & pkt 9) & $\mathrm{x}$ & pkt 7) & $\mathrm{X}$ & pkt 3) \\
\hline & 14. - - lad przestrzenny & $\mathrm{X}$ & pkt 1) & & & & \\
\hline & 15. - modernizacja terenów wiejskich & & & & & $\mathrm{X}$ & pkt 6) \\
\hline & 16. - obronność & & & $\mathrm{X}$ & pkt 20) & $\mathrm{X}$ & pkt 13) \\
\hline & 17. - ochrona praw konsumenta & & & $\mathrm{X}$ & pkt 18) & $\mathrm{X}$ & pkt 12) \\
\hline & $\begin{array}{l}\text { 18. - ochrona przeciwpowodziowa, w tym wyposażenie i utrzymanie } \\
\text { (gminnego, powiatowego, wojewódzkich) magazynu przeciwpowodziowego }\end{array}$ & $\mathrm{x}$ & pkt 14) & $\mathrm{x}$ & pkt 16) & $\mathrm{x}$ & pkt 9) \\
\hline & 19. - ochrona przeciwpożarowa & $\mathrm{x}$ & pkt 14) & $\mathrm{x}$ & pkt 16) & & \\
\hline & 20. - ochrona przyrody & $\mathrm{X}$ & pkt 1) & $\mathrm{x}$ & pkt 13) & & \\
\hline & 21. - ochrona środowiska & $\mathrm{X}$ & pkt 1) & $\mathrm{x}$ & pkt 13) & $\mathrm{x}$ & pkt 8) \\
\hline & 22. - ochrona zdrowia & $\mathrm{x}$ & pkt 5) & $\mathrm{x}$ & pkt 2) & $\mathrm{X}$ & pkt 2) \\
\hline
\end{tabular}




\begin{tabular}{|c|c|c|c|c|c|c|c|}
\hline & 23. - ośrodki i zakłady opiekuńcze & $\mathrm{X}$ & pkt 6) & & & & \\
\hline & 24. - polityka prorodzinna & $\mathrm{X}$ & pkt 16) & $\mathrm{X}$ & pkt 4) & $\mathrm{X}$ & pkt 5) \\
\hline & 25. - pomoc społeczna & $\mathrm{X}$ & pkt 6) & $\mathrm{x}$ & pkt 3) & $\mathrm{x}$ & pkt 4) \\
\hline & 26. - porządek publiczny i bezpieczeństwo obywateli & $\mathrm{x}$ & pkt 14) & $\mathrm{X}$ & pkt 15) & & \\
\hline & 27. - promocja (gminy, powiatu) & $\mathrm{X}$ & pkt 18) & $\mathrm{x}$ & pkt 21) & & \\
\hline & 28. - promocja zdrowia & & & $\mathrm{X}$ & pkt 2) & $\mathrm{X}$ & pkt 2) \\
\hline & 29. - przeciwdziałanie bezrobociu oraz aktywizacja lokalnego rynku pracy & & & $\mathrm{x}$ & pkt 17) & $\mathrm{x}$ & pkt 15) \\
\hline & 30. - rolnictwo, leśnictwo i rybołówstwo śródlądowe & & & $\mathrm{X}$ & pkt 14) & & \\
\hline & 31. - szkolnictwo wyższe & & & & & $\mathrm{x}$ & pkt 1) \\
\hline & 32. - targowiska i hale targowe & $\mathrm{X}$ & pkt 11) & & & & \\
\hline & 33. - tereny rekreacyjne i urządzenia sportowe & $\mathrm{X}$ & pkt 10) & & & & \\
\hline & 34. - transport zbiorowy lokalny & $\mathrm{X}$ & pkt 4) & & & & \\
\hline & 35. - transport zbiorowy i drogi publiczne & & & $\mathrm{x}$ & pkt 6) & $\mathrm{x}$ & pkt 10) \\
\hline & $\begin{array}{l}\text { 36. - utrzymanie (gminnych, powiatowych) obiektów i urządzeń użyteczności publicznej oraz obiektów } \\
\text { administracyjnych }\end{array}$ & $\mathrm{x}$ & pkt 15) & $\mathrm{X}$ & pkt 19) & & \\
\hline & $\begin{array}{l}\text { 37. - wodociagi i zaopatrzenie w wodę, kanalizacja, usuwanie i oczyszczanie ścieków komunalnych, } \\
\text { utrzymanie czystości, porządku oraz urządzeń sanitarnych, wysypisk i unieszkodliwiane odpadów } \\
\text { komunalnych, zaopatrzenie w energią elektryczną i cieplną oraz gaz }\end{array}$ & $\mathrm{X}$ & pkt 3) & & & & \\
\hline & $\begin{array}{l}\text { 38. - wspieranie i upowszechnianie idei samorządowej, w tym tworzenie warunków do działania } \\
\text { i rozwoju jednostek pomocniczych i wdrażanie programów pobudzania aktywności obywatelskiej }\end{array}$ & $\mathrm{X}$ & pkt 17) & & & & \\
\hline & 39. - wspieranie osób niepełnosprawnych & & & $\mathrm{X}$ & pkt 5) & & \\
\hline & $\begin{array}{l}\text { 40. - wspólpraca i działalność na rzecz organizacji pozarządowych oraz podmiotów wymienionych } \\
\text { w art. } 3 \text { ust. } 3 \text { ustawy o działalności pożytku publicznego i o wolontariacie }\end{array}$ & $\mathrm{x}$ & pkt 19) & $\mathrm{x}$ & pkt 22) & & \\
\hline & 41. - współpraca ze społecznościami lokalnymi i regionalnymi innych państw & $\mathrm{X}$ & pkt 20) & & & & \\
\hline & 42. - zagospodarowanie przestrzenne & & & & & $\mathrm{X}$ & pkt 7) \\
\hline & 43. - zapewnienie kobietom w ciąży opieki socjalnej, medycznej i prawnej & $\mathrm{x}$ & pkt 16) & & & & \\
\hline & 44. - zapobieganie innym nadzwyczajnym zagrożeniom życia i zdrowia ludzi oraz środowiska & & & $\mathrm{x}$ & pkt 16) & & \\
\hline & 45. - zieleń gminna i zadrzewienia & $\mathrm{x}$ & pkt 12) & & & & \\
\hline 2. & $\begin{array}{l}\text { Zapewnienie wykonywania określonych w ustawach zadań i kompetencji kierowników powiatowych } \\
\text { służb, }\end{array}$ & & & $\mathrm{x}$ & art. 4 ust. 2 & & \\
\hline
\end{tabular}




\begin{tabular}{|c|c|c|c|c|c|c|c|}
\hline \multirow{2}{*}{ Lp. } & \multirow{2}{*}{ Zakres działania } & \multicolumn{6}{|c|}{ Zadania publiczne } \\
\hline & & Gmina & przypis ustawy ${ }^{1}$ & Powiat & przypis ustawy $^{2}$ & Województwo & przypis ustawy \\
\hline 1. & $\begin{array}{l}\text { Zapewnienie wykonywania określonych w ustawach zadań i kompetencji kierowników powiatowych } \\
\text { służb, }\end{array}$ & & & $\mathrm{x}$ & art. 4 ust. 2 & & \\
\hline 2. & Zadania zlecone z zakresu administracji rządowej & $\mathrm{x}$ & art. 8 ust. 1 & $\mathrm{x}$ & art. 4 ust. 4 & $\mathrm{x}$ & art. 14 ust. 2 \\
\hline 3. & Zadania z zakresu organizacji przygotowań i przeprowadzenia wyborów powszechnych i referendów & $\mathrm{X}$ & art. 8 ust. 1 & $\mathrm{X}$ & art. $4 \mathrm{a}$ & $\mathrm{X}$ & art. 14 ust. 3 \\
\hline III. & ZADANIA POROZUMIENIOWE & & & & & & \\
\hline & 1. - zadania z zakresu właściwości gminy & - & & $\mathrm{x}$ & & & \\
\hline & 2. - zadania z zakresu właściwości powiatu & $\mathrm{x}$ & & - & & & \\
\hline & 3. - zadania z zakresu właściwości województwa & $\mathrm{X}$ & & $\mathrm{x}$ & & & \\
\hline
\end{tabular}

1 - ustawa z dnia 8 marca 1990 r. o samorządzie gminnym (tekst jednolity Dz. U. z 2001 r. Nr 142 poz. 1591 z późniejszymi zmianami)

2 - ustawa z dnia 5 czerwca 1998 r. o samorządzie powiatowym (tekst jednolity Dz. U. z 2001 r. Nr 142 poz. 1592 z późniejszymi zmianami)

3 - ustawa z dnia 5 czerwca 1998 r. o samorządzie województwa (tekst jednolity Dz. U. z 2001 r. Nr 142 poz. 1590 z późniejszymi zmianami)

Źródło: opracowanie własne na podstawie ustaw. 
Tabela 2. Zestawienie podziału zadań jednostki samorządu terytorialnego i źródeł ich finansowania

\begin{tabular}{|c|c|}
\hline Zadania publiczne (wydatki) & Źródta finansowania (dochody) \\
\hline \multicolumn{2}{|l|}{ I. ZADANIA WŁASNE } \\
\hline \multirow[t]{7}{*}{ Zadania publiczne własne } & Dochody własne \\
\hline & Udziały we wpływach z podatku dochodowego \\
\hline & Subwencja ogólna \\
\hline & $\begin{array}{l}\text { Dotacje celowe } \mathrm{z} \text { budżetu państwa na } \\
\text { finansowanie lub dofinansowanie zadań } \\
\text { własnych }\end{array}$ \\
\hline & $\begin{array}{l}\text { Dotacje celowe z budżetu państwa na } \\
\text { realizację zadań wynikających z umów } \\
\text { międzynarodowych }\end{array}$ \\
\hline & $\begin{array}{l}\text { Środki z funduszy celowych, pozyskiwane } \\
\text { na podstawie odrębnych przepisów }\end{array}$ \\
\hline & $\begin{array}{l}\text { Dotacje udzielane przez Narodowy Fundusz } \\
\text { Ochrony Środowiska i Gospodarki Wodnej } \\
\text { oraz wojewódzkie fundusze ochrony } \\
\text { środowiska i gospodarki wodnej na podstawie } \\
\text { odrębnych przepisów }\end{array}$ \\
\hline \multicolumn{2}{|l|}{ II. ZADANIA ZLECONE } \\
\hline $\begin{array}{l}\text { 1. Zapewnienie wykonywania określonych } \\
\text { w ustawach zadań i kompetencji } \\
\text { kierowników powiatowych służb, inspekcji } \\
\text { i straży }\end{array}$ & $\begin{array}{l}\text { 1. Dotacje celowe z budżetu państwa } \\
\text { na zadania z zakresu administracji rządowej } \\
\text { oraz na inne zadania zlecone ustawami }\end{array}$ \\
\hline $\begin{array}{l}\text { 2. Zadania zlecone z zakresu administracji } \\
\text { rządowej }\end{array}$ & $\begin{array}{l}\text { 2. Dotacje celowe z budżetu państwa } \\
\text { na zadania z zakresu administracji rządowej } \\
\text { oraz na inne zadania zlecone ustawami }\end{array}$ \\
\hline $\begin{array}{l}\text { 3. Zadania z zakresu organizacji przygotowań } \\
\text { i przeprowadzenia wyborów powszechnych } \\
\text { i referendów }\end{array}$ & $\begin{array}{l}\text { 3. Dotacje celowe z budżetu państwa } \\
\text { na zadania z zakresu administracji rządowej } \\
\text { oraz na inne zadania zlecone ustawami }\end{array}$ \\
\hline \multicolumn{2}{|l|}{ III. ZADANIA POROZUMIENIOWE } \\
\hline $\begin{array}{l}\text { Zadania z zakresu administracji rządowej } \\
\text { na podstawie porozumień z organami tej } \\
\text { administracji }\end{array}$ & $\begin{array}{l}\text { 1. Dotacje celowe z budżetu państwa } \\
\text { na zadania realizowane przez jednostki } \\
\text { samorządu terytorialnego na mocy porozumień } \\
\text { zawartych z organami administracji rządowej }\end{array}$ \\
\hline $\begin{array}{l}\text { 2. Zadania z zakresu właściwości innych } \\
\text { jednostek samorządu terytorialnego na } \\
\text { podstawie porozumień z tymi jednostkami }\end{array}$ & $\begin{array}{l}\text { 2. Dotacje z budżetów innych jednostek } \\
\text { samorządu terytorialnego }\end{array}$ \\
\hline
\end{tabular}

Źródło: opracowanie własne.

$\mathrm{Na}$ bazie tego zestawienia przeprowadzono szczególową analizę adekwatności środków do zadań jednostek samorządu terytorialnego.

\section{Koncepcja podziału zadań jednostki samorzadu terytorialnego według kryterium kompetencyjno-finansowego}

W polskich uwarunkowaniach zarówno gmina, jak i powiat stanowią lokalny samorząd terytorialny realizujący zadania publiczne na jak najniższym poziomie przy zapewnieniu, zgodnie z zasadą adekwatności, niezbędnych na ten cel środków. Zakres zadań i kompetencji oraz zapewnienie na ten cel środków, określają ustawy.

Biorac pod uwage presję wydatków bieżących oraz zaostrzenie polityki transferowej z budżetu państwa poprzez przekazywanie nowych zadań bez precyzyjnego zabezpieczenia na ten cel środków, należy uznać za niezwykle ważne badanie adekwatności środków finansowych. $\mathrm{Na}$ 
łamach czasopisma „Finanse Komunalne” poruszane są coraz częściej problemy finansów samorządu w związku z przekazywaniem przez rząd nowych zadań, za którymi nie idą środki adekwatne do kosztów ich realizacji. Ogólnopolskie korporacje samorządowe (Związek Miast Polskich, Związek Gmin Wiejskich RP, Unia Miasteczek, Związek Powiatów Polskich) podejmują inicjatywę mającą na celu zrekompensowanie samorządom wydatków ponoszonych w związku z dodatkowymi obowiązkami nakładanymi przez państwo kolejnymi ustawami, poprzez przedłożenie Sejmowi obywatelskiego projektu ustawy o dochodach jednostek samorządu terytorialnego zwiększającego udział poszczególnych szczebli samorządu w podatku PIT oraz wprowadzającego tzw. subwencję ekologiczną dla gmin objętych terenami chronionymi. Wskazać tu należy opinię T. Dębowskiej-Romanowskiej: „Sama zasada adekwatności źródeł dochodów samorządu terytorialnego, choć ma zadania gwarancyjne oraz jest norma o charakterze zjuryzdyzowanym o dużym znaczeniu orzeczniczym, ze swej natury jest zdana na niepewne i trudne do przewidzenia orzecznictwo TK i sądów administracyjnych" (Dębowska-Romanowska, 2014). Jak wskazuje T. Dębowska-Romanowska, istnieje trudność $\mathrm{z}$ jednoznaczną odpowiedzią, jak mierzyć nieadekwatność finansowania zadań dochodami.

Kolejnym krokiem działań samorządów jest wystąpienie ze społeczną akcją pod hasłem "Stop Janosikowe” i złożenie przez Radę Miasta Stołecznego Warszawy i Radę Miasta Krakowa wniosku do Trybunału Konstytucyjnego w sprawie konstytucyjności zasad pobierania tzw. janosikowego (obowiązkowych wpłat do budżetu państwa przez najbogatsze samorządy z przeznaczeniem na wyrównanie sytuacji finansowej samorządów biedniejszych). Trybunał Konstytucyjny w wyroku z dnia 4 marca 2014 r. (w związku z wnioskiem Sejmiku Województwa Mazowieckiego²) stwierdził, iż niezasadny jest zarzut, „że wpłaty wyrównawcze nie przyczyniają się do poprawy kondycji finansowej ich beneficjentów". W uzasadnieniu wyroku Trybunał wskazał, że „wszelkie uzyskane przez transfery poziome środki zwiększają zasoby finansowe pozostające do dyspozycji woje- wództw będących beneficjentami części regionalnej, umożliwiając im sfinansowanie różnych zadań publicznych. Teza, zgodnie z którą cel wprowadzenia instytucji wpłat wyrównawczych zostanie osiagniety pod warunkiem, że słabsze finansowo i uzyskujące środki pochodzące $\mathrm{z}$ wpłat JST będą miały obowiązek przeznaczenia tych środków w sposób gwarantujący poprawę ich sytuacji finansowej, pomija istotny fakt, że wpłaty wyrównawcze pełnią funkcję korekcyjno-systemową i nie są związane $z$ finansowaniem konkretnego zadania publicznego powierzonego jednostkom samorządu terytorialnego"3.

Adekwatność i powiązana z nią problematyka samodzielności jednostek samorządu terytorialnego poruszane są również w debatach w ramach konferencji Finansów Komunalnych. J. Glumińska-Pawlic w swoim wystąpieniu stwierdza, że wieloletnie wyniki prac zespołów nad zmianą źródeł dochodów ,znikały wraz z kolejnymi wyborami do parlamentu" (Glumińska-Pawlic, 2014).

Na szereg dysfunkcji w funkcjonowaniu systemu finansowania jednostek samorządu terytorialnego, w tym na dysfunkcje w obszarze subwencjonowania jednostek samorządu terytorialnego wskazała też A. Sekuła (Sekuła, 2016, s. 222-228).

Powyższe wskazuje, jak ważna jest problematyka adekwatności środków do zadań jednostek samorządu terytorialnego. Mając na względzie kompetencje ustawowe oraz źródła finansowania, zasadne jest zaproponowanie następujących trzech grup zadań:

1) rządowych,

2) samorządowo-rządowych,

3) samorządowych.

Pod pojęciem „zadania rządowe” należy rozumieć zadania zlecone z zakresu administracji rządowej, a także organizacji przygotowań i przeprowadzenia wyborów powszechnych oraz referendów, których obowiązek wykonania nakładają na jednostki samorządu terytorialnego - gminę, powiat, województwo - ustawy lub porozumienia z organami administracji rządowej, charakteryzujące się zabezpieczeniem finansowym w wysokości koniecznej do ich wykonania w formie dotacji celowej $\mathrm{z}$ budżetu państwa na zadania zlecone z mocy ustaw oraz dotacji na zadania zle- 
Rysunek 1. Zadania rządowe i źródła ich finansowania

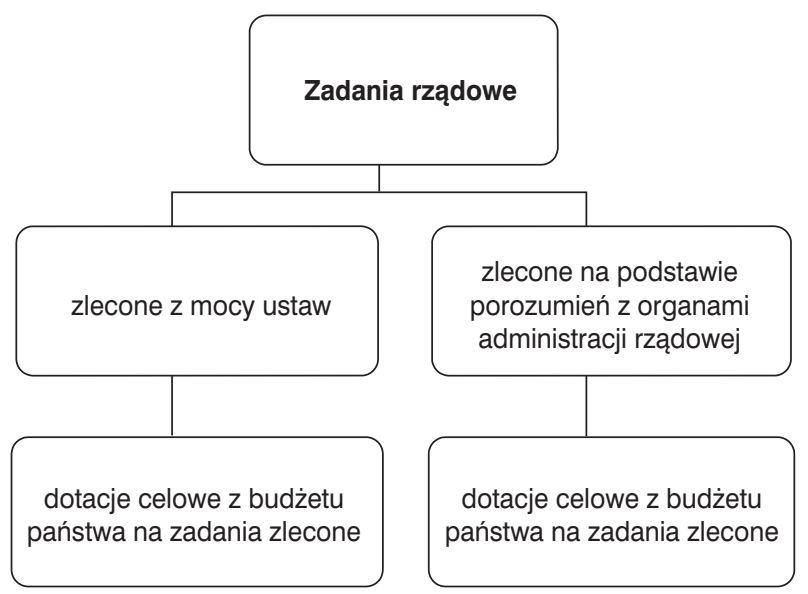

Źródło: opracowanie własne.

cone $z$ mocy porozumień $z$ organami administracji rządowej. Finansowanie zadań rządowych ujęte jest w ustawie budżetowej państwa na dany rok budżetowy w poszczególnych częściach budżetowych oraz rezerwach celowych (część 83).

Pod pojęciem ,zadania samorządoworządowe" należy rozumieć nowe zadania przekazane jednostce samorządu teryto- rialnego - gminie, powiatowi, województwu - w drodze ustawy, charakteryzujące się zabezpieczeniem finansowym w wysokości koniecznej do ich realizacji w postaci zwiększenia dochodów własnych, subwencji oraz dotacji celowej z budżetu państwa na finansowanie lub dofinansowanie zadań własnych. Kategoria ta obejmuje również zadania realizowane w ramach programów

Rysunek 2. Zadania samorządowo-rządowe i źródła ich finansowania

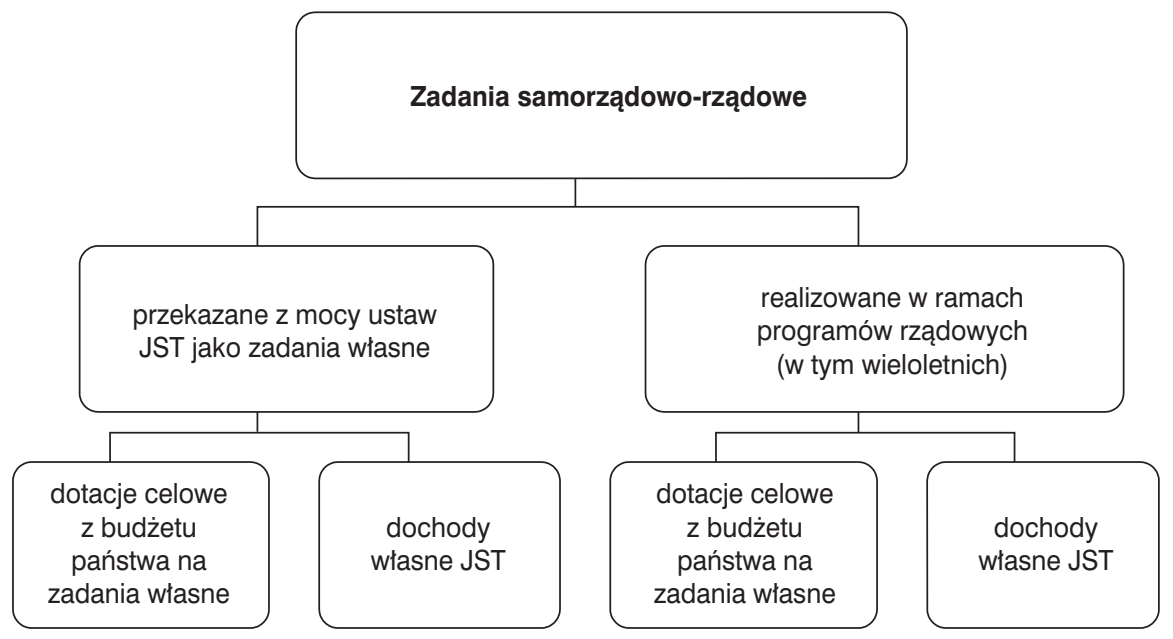

Źródło: opracowanie własne.

Wydział Zarządzania UW ～DOI 10.7172/1733-9758.2017.25.9 
rządowych. Finansowanie tych zadań ujęte jest w ustawie budżetowej państwa na dany rok budżetowy w poszczególnych częściach budżetowych oraz rezerwach celowych (część 83).

„Zadania samorzadowe" to zadania realizowane przez jednostki samorządu terytorialnego - gminę, powiat, wojewódz- two - wynikające $\mathrm{z}$ ustaw samorządowych oraz ustaw merytorycznych, których źródła finansowania określa ustawa o dochodach jednostek samorządu terytorialnego, jako dochody własne oraz udziały i subwencje. Kategoria ta obejmuje również zadania realizowane w ramach porozumień między jednostkami samorządu terytorialnego oraz zadania współfinansowane środkami euro-

Rysunek 3. Zadania samorządowe i źródła ich finansowania

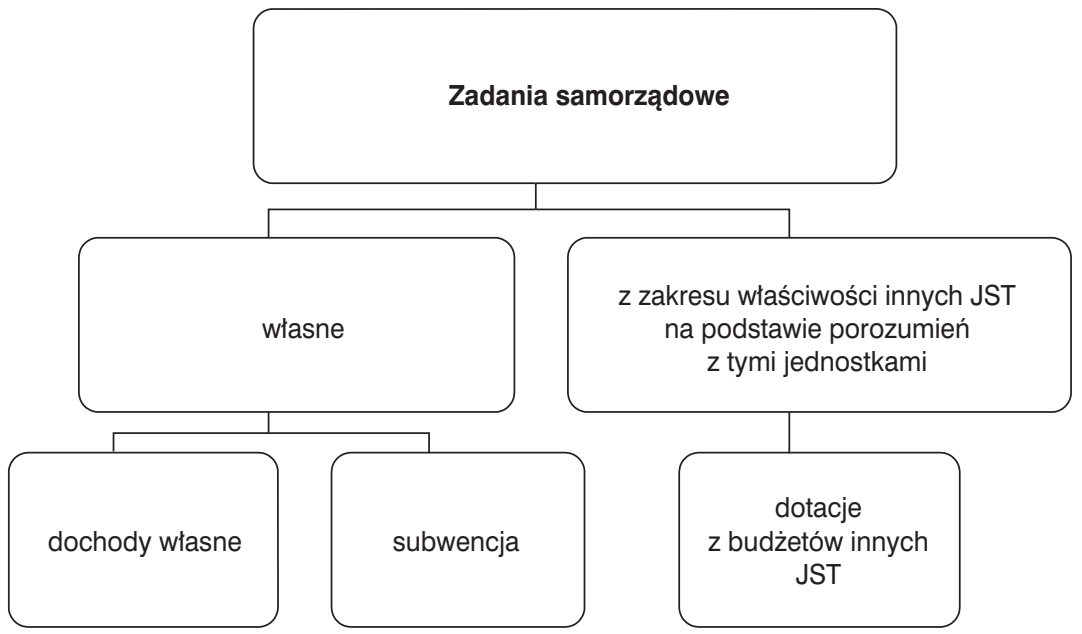

Źródło: opracowanie własne.

pejskimi. Finansowanie tych zadań ujęte jest w uchwałach budżetowych jednostek samorządu terytorialnego, a w przypadku finansowania wieloletniego również w Wieloletnich Prognozach Finansowych (przedsięwzięcia).

Przedstawiony podział zadań różni się od dotychczas spotykanych $\mathrm{w}$ literaturze. $\mathrm{Ma}$ on na celu powiązanie realizowanych zadań ze źródłami ich finansowania.

\section{Zróżnicowanie poziomu}

\section{dofinansowania zadań rządowych} na przykładzie wybranych miast

Na podstawie powyższych założeń dokonano wstępnej analizy poziomu wydatków na zadania rządowe na przykładzie miast: Kraków, Poznań, Szczecin, biorąc pod uwagę źródła finansowania, co daje możliwość oceny sformułowanego przez ustawodawcę ,zabezpieczenia finansowego w wysokości koniecznej do ich realizacji (por. tabela 3). Studium przypadku wskazuje, iż miasto Szczecin w latach 2011-2017 dofinansowało ze środków własnych 5 zadań zleconych z mocy ustaw na poziomie od 7,5 do $12,8 \mathrm{mln} \mathrm{zl}$, tj. od $7,1 \%$ do $11,4 \%$ w stosunku do otrzymanych dotacji celowych z budżetu państwa na ich finansowanie. Analogiczne zadania rządowe dofinansowało miasto Poznań na poziomie od 4,4 do 8,5 mln zł (tj. od 3,9\% do $7,9 \%$ otrzymanych dotacji) oraz miasto Kraków na poziomie 4,4 do $11,2 \mathrm{mln}$ zł (tj. od 2,6\% do $6,9 \%$ otrzymanych dotacji). W praktyce oznacza to wyższe potrzeby w stosunku do otrzymanych środków, a tym samym naruszenie zasady adekwatności środków do zadań. Podobna sytuacja ma miejsce również w innych miastach metropolitalnych. Odpowiedź na pytanie 


\begin{tabular}{|c|c|c|c|c|c|c|c|c|c|c|}
\hline \multirow[b]{2}{*}{ Lp. } & & & \multirow[b]{2}{*}{ Zadania rządowe } & \multicolumn{7}{|c|}{ Kraków } \\
\hline & \multicolumn{2}{|c|}{ Rozdz. } & & $\begin{array}{c}2011 \text { rok } \\
\text { Wykonanie }\end{array}$ & $\begin{array}{c}2012 \text { rok } \\
\text { Wykonanie }\end{array}$ & $\begin{array}{c}2013 \text { rok } \\
\text { Wykonanie }\end{array}$ & $\begin{array}{c}2014 \text { rok } \\
\text { Wykonanie }\end{array}$ & $\begin{array}{c}2015 \text { rok } \\
\end{array}$ & 2016 rok & $\begin{array}{l}2017 \text { rok } \\
\text { Plan }\end{array}$ \\
\hline \multirow[t]{7}{*}{1.} & 71015 & & Nadzór budowlany & & & & & & & \\
\hline & & 1. & Dotacja z budżetu państwa na zadania zlecone z mocy ustaw & 3382208 & 3385753 & 3376919 & 3309466 & 3465536 & 3826014 & 3810040 \\
\hline & & 2. & Wydatki na realizację zadania & 3447201 & 3450734 & 3441871 & 3407462 & 3583515 & 3924011 & 3810040 \\
\hline & & & - wydatki bieżące & 3447201 & 3450734 & 3441871 & 3397462 & 3498543 & 3924011 & 3773040 \\
\hline & & & - wydatki majątkowe & 0 & 0 & 0 & 10000 & 84972 & 0 & 37000 \\
\hline & & 3. & Kwota dofinansowania z budżetu miasta & 64993 & 64981 & 64952 & 97996 & 117979 & 97997 & 0 \\
\hline & & 4. & Wskaźnik poziomu dofinansowania wydatków z budżetu miasta & $1,9 \%$ & $1,9 \%$ & $1,9 \%$ & $2,9 \%$ & $3,3 \%$ & $2,5 \%$ & $0,0 \%$ \\
\hline \multirow[t]{7}{*}{2.} & 75011 & & Urzędy wojewódzkie & & & & & & & \\
\hline & & 1. & Dotacja z budżetu państwa na zadania zlecone z mocy ustaw & 7106252 & 7066890 & 7229822 & 6664426 & 8302325 & 8571859 & 5847846 \\
\hline & & 2. & Wydatki na realizację zadania & 7106252 & 7066890 & 7229822 & 6664426 & 8302325 & 8571859 & 5847846 \\
\hline & & & - wydatki bieżące & 7106252 & 7066890 & 7229822 & 6664426 & 8302325 & 8571859 & 5847846 \\
\hline & & & - wydatki majątkowe & 0 & 0 & 0 & 0 & 0 & 0 & 0 \\
\hline & & 3. & Kwota dofinansowania z budżetu miasta & 0 & 0 & 0 & 0 & 0 & 0 & 0 \\
\hline & & 4. & Wskaźnik poziomu dofinansowania wydatków z budżetu miasta & $0,0 \%$ & $0,0 \%$ & $0,0 \%$ & $0,0 \%$ & $0,0 \%$ & $0,0 \%$ & $0,0 \%$ \\
\hline \multirow[t]{7}{*}{3.} & 75411 & & Komendy powiatowe Państwowej Straży Pożarnej & & & & & & & \\
\hline & & 1. & Dotacja z budżetu państwa na zadania zlecone z mocy ustaw & 39688538 & 41433196 & 42920533 & 42959711 & 42856549 & 46672010 & 43114357 \\
\hline & & 2. & Wydatki na realizację zadania & 41776522 & 43179941 & 45874589 & 44672092 & 50582447 & 48413075 & 44490628 \\
\hline & & & - wydatki bieżące & 39837687 & 41533124 & 43629218 & 43524842 & 43573705 & 47163050 & 43732057 \\
\hline & & & - wydatki majątkowe & 1938835 & 1646817 & 2245371 & 1147250 & 7008742 & 1250025 & 758571 \\
\hline & & 3. & Kwota dofinansowania z budżetu miasta & 2087984 & 1746745 & 2954056 & 1712381 & 7725898 & 1741065 & 1376271 \\
\hline & & 4. & Wskaźnik poziomu dofinansowania wydatków z budżetu miasta & $5,0 \%$ & $4,0 \%$ & $6,4 \%$ & $3,8 \%$ & $15,3 \%$ & $3,6 \%$ & $3,1 \%$ \\
\hline \multirow[t]{2}{*}{4.} & 85156 & & $\begin{array}{l}\text { Składki na ubezpieczenia zdrowotne oraz świadczenia dla osób } \\
\text { nieobjętych obowiązkiem ubezpieczenia zdrowotnego }\end{array}$ & & & & & & & \\
\hline & & 1. & Dotacja z budżetu państwa na zadania zlecone z mocy ustaw & 10614317 & 12808715 & 15850687 & 15320418 & 13502928 & 11884151 & 11174505 \\
\hline
\end{tabular}




\begin{tabular}{|c|c|c|c|c|c|c|c|c|c|c|}
\hline \multirow{3}{*}{ Lp. } & & & \multirow[b]{3}{*}{ Wydatki na realizację zadania } & \multicolumn{7}{|c|}{ Kraków } \\
\hline & \multicolumn{2}{|c|}{ Rozdz. } & & $\begin{array}{c}2011 \text { rok } \\
\text { Wykonanie }\end{array}$ & $\begin{array}{c}2012 \text { rok } \\
\text { Wykonanie }\end{array}$ & $\begin{array}{c}2013 \text { rok } \\
\text { Wykonanie }\end{array}$ & $\begin{array}{c}2014 \text { rok } \\
\text { Wykonanie }\end{array}$ & $\begin{array}{c}2015 \text { rok } \\
\text { Wykonanie }\end{array}$ & $\begin{array}{c}2016 \text { rok } \\
\text { Wykonanie }\end{array}$ & $\begin{array}{l}2017 \text { rok } \\
\text { Plan } \\
\text { na } 01.01\end{array}$ \\
\hline & & 2. & & 10615436 & 12810271 & 15851674 & 15320792 & 13504330 & 11884292 & 11175705 \\
\hline & & & - wydatki bieżące & 10615436 & 12810271 & 15851674 & 15320792 & 13504330 & 11884292 & 11175705 \\
\hline & & & - wydatki majątkowe & 0 & 0 & 0 & 0 & 0 & 0 & \\
\hline & & 3. & Kwota dofinansowania $\mathrm{z}$ budżetu miasta & 1119 & 1556 & 987 & 374 & 1402 & 141 & 1200 \\
\hline & & 4. & Wskaźnik poziomu dofinansowania wydatków z budżetu miasta & $0,0 \%$ & $0,0 \%$ & $0,0 \%$ & $0,0 \%$ & $0,0 \%$ & $0,0 \%$ & $0,0 \%$ \\
\hline \multirow[t]{7}{*}{5.} & $\begin{array}{c}85212 \\
85502 \\
\text { (od } \\
2017 \text { r.) }\end{array}$ & & $\begin{array}{l}\text { Świadczenia rodzinne, świadczenia z funduszu alimentacyjnego } \\
\text { oraz składki na ubezpieczenia emerytalne i rentowe } \\
\text { z ubezpieczenia społecznego }\end{array}$ & & & & & & & \\
\hline & & 1. & Dotacja z budżetu państwa na zadania zlecone z mocy ustaw & 98395240 & 96149082 & 92852130 & 93598607 & 96438918 & 114608368 & 109525326 \\
\hline & & 2. & Wydatki na realizację zadania & 104704315 & 105499900 & 97795404 & 96176545 & 99190434 & 117574859 & 112835826 \\
\hline & & & - wydatki bieżące & 104704315 & 105499900 & 97795404 & 96176545 & 99190434 & 117574859 & 112835826 \\
\hline & & & - wydatki majątkowe & 0 & 0 & 0 & 0 & 0 & 0 & 0 \\
\hline & & 3. & Kwota dofinansowania z budżetu miasta & 6309075 & 9350818 & 4943274 & 2577938 & 2751516 & 2966491 & 3310500 \\
\hline & & 4. & Wskaźnik poziomu dofinansowania wydatków z budżetu miasta & $6,0 \%$ & $8,9 \%$ & $5,1 \%$ & $2,7 \%$ & $2,8 \%$ & $2,5 \%$ & $2,9 \%$ \\
\hline \multirow[t]{7}{*}{6.} & 85321 & & Zespoły ds. orzekania o stopniu niepełnosprawności & & & & & & & \\
\hline & & 1. & Dotacja z budżetu państwa na zadania zlecone z mocy ustaw & 965334 & 1261696 & 1061738 & 1163179 & 1563380 & 1218592 & 922043 \\
\hline & & 2. & Wydatki na realizację zadania & 965334 & 1261696 & 1061738 & 1163179 & 1563380 & 1218592 & 922043 \\
\hline & & & - wydatki bieżące & 965334 & 1261696 & 1061738 & 1163179 & 1563380 & 1218592 & 922043 \\
\hline & & & - wydatki majątkowe & 0 & 0 & 0 & 0 & 0 & 0 & 0 \\
\hline & & 3. & Kwota dofinansowania z budżetu miasta & 0 & 0 & 0 & 0 & 0 & 0 & 0 \\
\hline & & 4. & Wskaźnik poziomu dofinansowania wydatków z budżetu miasta & $0,0 \%$ & $0,0 \%$ & $0,0 \%$ & $0,0 \%$ & $0,0 \%$ & $0,0 \%$ & $0,0 \%$ \\
\hline
\end{tabular}




\begin{tabular}{|c|c|c|c|c|c|c|c|c|c|c|}
\hline \multirow[b]{2}{*}{ Lp. } & & & \multirow[b]{2}{*}{ Zadania rządowe } & \multicolumn{7}{|c|}{ Poznań } \\
\hline & \multicolumn{2}{|c|}{ Rozdz. } & & $\begin{array}{c}2011 \text { rok } \\
\text { Wykonanie }\end{array}$ & $\begin{array}{c}2012 \text { rok } \\
\text { Wykonanie }\end{array}$ & $\begin{array}{c}2013 \text { rok } \\
\text { Wykonanie }\end{array}$ & $\begin{array}{c}2014 \text { rok } \\
\text { Wykonanie }\end{array}$ & $\begin{array}{c}2015 \text { rok } \\
\text { Wykonanie }\end{array}$ & $\begin{array}{c}2016 \text { rok } \\
\text { Wykonanie }\end{array}$ & $\begin{array}{c}2017 \text { rok } \\
\text { Plan } \\
\text { na } 01.01\end{array}$ \\
\hline & & 1. & Dotacja z budżetu państwa na zadania zlecone z mocy ustaw & 1141284 & 1229437 & 1278564 & 1277415 & 1310593 & 1324679 & 1259000 \\
\hline & & 2. & Wydatki na realizację zadania & 1804278 & 1892416 & 1941557 & 1940407 & 1993582 & 2007623 & 1942000 \\
\hline & & & - wydatki bieżące & 1804278 & 1892416 & 1941557 & 1940407 & 1993582 & 2007623 & 1942000 \\
\hline & & 4. & Wskaźnik poziomu dofinansowania wydatków z budżetu miasta & $36,7 \%$ & $35,0 \%$ & $34,1 \%$ & $34,2 \%$ & $34,3 \%$ & $34,0 \%$ & $35,2 \%$ \\
\hline \multirow[t]{4}{*}{2.} & 75011 & & Urzędy wojewódzkie & & & & & & & \\
\hline & & 1. & Dotacja z budżetu państwa na zadania zlecone z mocy ustaw & 4350989 & 4834200 & 5013434 & 5164195 & 6533701 & 7449952 & 5524139 \\
\hline & & 2. & Wydatki na realizację zadania & 4350989 & 4834200 & 5013434 & 5164195 & 6533701 & 7449952 & 5524139 \\
\hline & & & - wydatki bieżące & 4350989 & 4834200 & 5013434 & 5164195 & 6533701 & 7449952 & 5524139 \\
\hline & & 1. & Dotacja z budżetu państwa na zadania zlecone z mocy ustaw & 34357670 & 34236730 & 36489160 & 37725764 & 35576124 & 37300069 & 37886000 \\
\hline & & 2. & Wydatki na realizację zadania & 36218170 & 38979380 & 37476004 & 38819839 & 37529885 & 39098591 & 43237310 \\
\hline & & & - wydatki bieżące & 32988175 & 34005330 & 35215489 & 35751238 & 35654339 & 37542991 & 36591000 \\
\hline & & & - wydatki majątkowe & 3229995 & 4974050 & 2260515 & 3068601 & 1875546 & 1555600 & 6646310 \\
\hline & & 3. & Kwota dofinansowania $\mathrm{z}$ budżetu miasta & 1860500 & 4742650 & 986844 & 1094075 & 1953761 & 1798522 & 5351310 \\
\hline & & 4. & Wskaźnik poziomu dofinansowania wydatków z budżetu miasta & $5,1 \%$ & $12,2 \%$ & $2,6 \%$ & $2,8 \%$ & $5,2 \%$ & $4,6 \%$ & $12,4 \%$ \\
\hline 4. & 85156 & & $\begin{array}{l}\text { Składki na ubezpieczenia zdrowotne oraz świadczenia dla osób } \\
\text { nieobjętych obowiązkiem ubezpieczenia zdrowotnego }\end{array}$ & & & & & & & \\
\hline & & 1. & Dotacja z budżetu państwa na zadania zlecone z mocy ustaw & 58968 & 57848 & 58436 & 60466 & 61905 & 55879 & 58968 \\
\hline
\end{tabular}




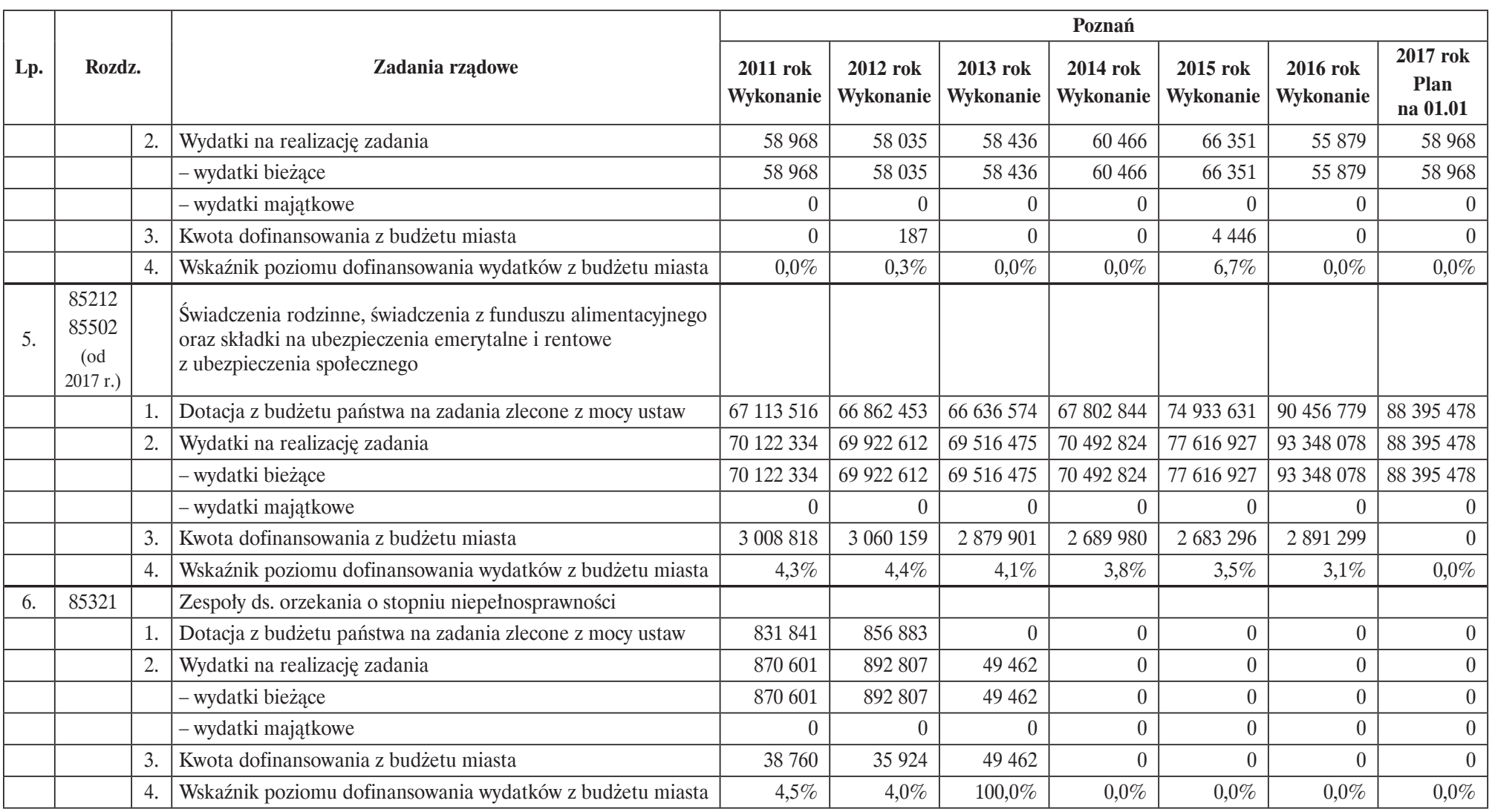




\begin{tabular}{|c|c|c|c|c|c|c|c|c|c|c|}
\hline \multirow[b]{2}{*}{ Lp. } & \multirow{2}{*}{\multicolumn{2}{|c|}{ Rozdz. }} & \multirow[b]{2}{*}{ Zadania rządowe } & \multicolumn{7}{|c|}{ Szczecin } \\
\hline & & & & $\begin{array}{c}2011 \text { rok } \\
\text { Wykonanie }\end{array}$ & $\begin{array}{c}2012 \text { rok } \\
\text { Wykonanie }\end{array}$ & $\begin{array}{c}2013 \text { rok } \\
\text { Wykonanie }\end{array}$ & $\begin{array}{c}2014 \text { rok } \\
\text { Wykonanie }\end{array}$ & $\begin{array}{c}2015 \text { rok } \\
\text { Wykonanie }\end{array}$ & $\begin{array}{c}2016 \text { rok } \\
\text { Wykananip }\end{array}$ & $\begin{array}{l}2017 \text { rok } \\
\text { Plan na }\end{array}$ \\
\hline \multirow[t]{7}{*}{1.} & 71015 & & Nadzór budowlany & & & & & & & \\
\hline & & 1. & Dotacja z budżetu państwa na zadania zlecone z mocy ustaw & 876723 & 876075 & 894507 & 984995 & 1057071 & 1105062 & 1117000 \\
\hline & & 2. & Wydatki na realizację zadania & 1657007 & 1625305 & 1659847 & 1572172 & 1655019 & 1740463 & 1754745 \\
\hline & & & - wydatki bieżące & 1657007 & 1615457 & 1626847 & 1572172 & 1655019 & 1740463 & 1754745 \\
\hline & & & - wydatki majątkowe & 0 & 9848 & 33000 & 0 & 0 & 0 & 0 \\
\hline & & 3. & Kwota dofinansowania z budżetu miasta & 780284 & 749230 & 765340 & 587177 & 597948 & 635401 & 637745 \\
\hline & & 4. & Wskaźnik poziomu dofinansowania wydatków z budżetu miasta & $47,1 \%$ & $46,1 \%$ & $46,1 \%$ & $37,3 \%$ & $36,1 \%$ & $36,5 \%$ & $36,3 \%$ \\
\hline \multirow[t]{7}{*}{2.} & 75011 & & Urzędy wojewódzkie & & & & & & & \\
\hline & & 1. & Dotacja z budżetu państwa na zadania zlecone z mocy ustaw & 2734298 & 2733800 & 2680500 & 3498300 & 5611835 & 4527520 & 2724900 \\
\hline & & 2. & Wydatki na realizację zadania & 8502358 & 8319514 & 7953410 & 8022962 & 8585990 & 7088759 & 8137440 \\
\hline & & & - wydatki bieżące & 8502358 & 8319514 & 7953410 & 8022962 & 8585990 & 7088759 & 8137440 \\
\hline & & & - wydatki majątkowe & 0 & 0 & 0 & 0 & 0 & 0 & 0 \\
\hline & & 3. & Kwota dofinansowania $\mathrm{z}$ budżetu miasta & 5768060 & 5585714 & 5272910 & 4524662 & 2974155 & 2561239 & 5412540 \\
\hline & & 4. & Wskaźnik poziomu dofinansowania wydatków z budżetu miasta & $67,8 \%$ & $67,1 \%$ & $66,3 \%$ & $56,4 \%$ & $34,6 \%$ & $36,1 \%$ & $66,5 \%$ \\
\hline \multirow[t]{7}{*}{3.} & 75411 & & Komendy powiatowe Państwowej Straży Pożarnej & & & & & & & \\
\hline & & 1. & Dotacja z budżetu państwa na zadania zlecone z mocy ustaw & 20302814 & 20075731 & 20819877 & 20835472 & 20783116 & 21493828 & 21588000 \\
\hline & & 2. & Wydatki na realizację zadania & 20549975 & 20223823 & 20819877 & 21519322 & 22372980 & 26329423 & 22948000 \\
\hline & & & - wydatki bieżące & 19525959 & 20047751 & 20819877 & 20667841 & 20748491 & 21470868 & 21708000 \\
\hline & & & - wydatki majątkowe & 1024016 & 176072 & 0 & 851481 & 1624489 & 4858555 & 1240000 \\
\hline & & 3. & Kwota dofinansowania z budżetu miasta & 247161 & 148092 & 0 & 683850 & 1589864 & 4835595 & 1360000 \\
\hline & & 4. & Wskaźnik poziomu dofinansowania wydatków z budżetu miasta & $1,2 \%$ & $0,7 \%$ & $0,0 \%$ & $3,2 \%$ & $7,1 \%$ & $18,4 \%$ & $5,9 \%$ \\
\hline \multirow[t]{2}{*}{4.} & 85156 & & $\begin{array}{l}\text { Składki na ubezpieczenia zdrowotne oraz świadczenia dla osób } \\
\text { nieobjętych obowiązkiem ubezpieczenia zdrowotnego }\end{array}$ & & & & & & & \\
\hline & & 1. & Dotacja z budżetu państwa na zadania zlecone z mocy ustaw & 10642329 & 11597875 & 12775256 & 12339709 & 10039613 & 7308368 & 7532000 \\
\hline
\end{tabular}




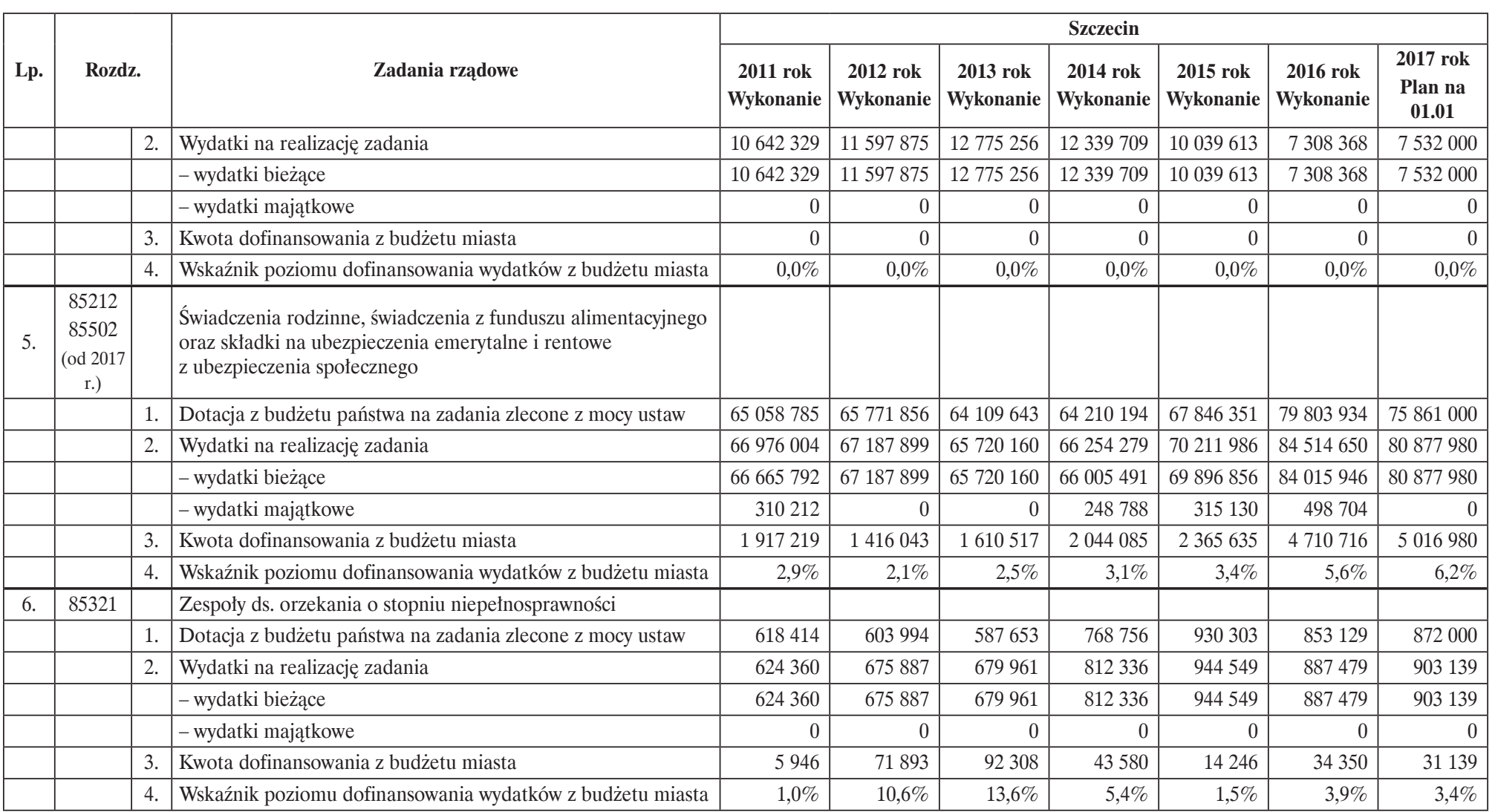

Źródło: opracowanie własne. 
o przyczyny dofinansowania zadań rządowych i ich zróżnicowania wymaga dodatkowych badań (trudności z procesem rzetelnego planowania, zdarzenia niezależne od miast itp.). Wskazuje to na złożoność kategorii adekwatności.

\section{Wieloletni program „Pomoc państwa w zakresie dożywiania" jako zadanie samorządowo- rządowe}

Dla zadań samorządowo-rządowych poddano z kolei analizie specyfikę pomiaru efektów wydatkowanych środków publicznych przez sektor rządowy i samorządowy dla wybranego wieloletniego programu rządowego „Pomoc państwa w zakresie dożywiania" i jego realizacji w latach 2011-2013. Jednym z załączników ustawy budżetowej jest część poświęcona programom wieloletnim. Programy te prezentowane są według formuły tzw. zadaniowego planu wydatków. Wydatki budżetu państwa przypisane są tu do odpowiednich poziomów klasyfikacji zadaniowej według kryterium celu, któremu służą. Pomiar celów realizowany jest za pomocą mierników efektów w postaci tzw. produktów, rezultatów i mierników oddziaływania. Program będący przedmiotem analizy w artykule jest umieszczony w klasyfikacji zadaniowej na poziomie działania, stanowiący składową podzadania „Wspieranie osób zagrożonych wykluczeniem społecznym". Podzadanie to zaś stanowi jedno z sześciu podzadań zadania „Pomoc i integracja społeczna”. Zadanie "pomoc i integracja społeczna” jest jednym z siedmiu zadań funkcji 13. - „Zabezpieczenie społeczne i wspieranie rodziny". Środki na realizację programu w danym roku budżetowym umieszczone są w ustawie budżetowej w ramach części 83 Rezerwy ogólne i celowe w „Różnych rozliczeniach" - rozdział 75818 .

Program rządowy przyjęty ustawą z dnia 29 grudnia 2005 r. o ustanowieniu programu wieloletniego „Pomoc państwa w zakresie dożywiania" (z późniejszymi zmianami) ukierunkowany został na wparcie gmin w wypełnianiu zadań własnych o charakterze obowiązkowym w zakresie dożywiania dzieci oraz zapewnieniu posiłku osobom jego pozbawionych. Odbiorcami Programu są dzieci do 7. roku życia, uczniowie do czasu ukończenia szkoły ponadgimnazjalnej oraz osoby i rodziny znajdujące się w sytuacji: ubóstwa, sieroctwa, bezdomności, bezrobocia, długotrwałej lub ciężkiej choroby, przemocy w rodzinie, wielodzietności, bezradności w sprawach opiekuńczo - wychowawczych i prowadzenia gospodarstwa domowego, zwłaszcza w rodzinach niepełnych lub wielodzietnych, zdarzenia losowego, sytuacji kryzysowej, w szczególności osoby samotne, w podeszłym wieku, chore lub niepełnosprawne. Osoby uprawnione na mocy Programu mogą otrzymać pomoc w formie: posiłku, świadczenia pieniężnego w postaci zasiłku celowego na zakup posiłku lub żywności, świadczenia rzeczowego w postaci produktów żywnościowych. Ponadto Program przewiduje wsparcie w zakresie tworzenia nowych lub doposażenia istniejących punktów przygotowania lub wydawania posiłków, jak również dowozu posiłków.

Warunki udzielania dotacji celowej z budżetu państwa na realizację Programu określają udział własny gminy na poziomie nie mniejszym niż $40 \%$ przewidywanych kosztów realizacji zadania. Na uzasadniony wniosek wojewoda może wyrazić zgodę na zwiększenie dotacji, jednak pod warunkiem iż udział własny gminy nie może być niższy niż 20\% przewidywanych kosztów realizacji zadania. Dotacja przyznawana jest na podstawie porozumienia $\mathrm{z}$ wojewodą, a jej wysokość ustalana jest ze szczególnym uwzględnieniem liczby dzieci i młodzieży oraz innych osób wymagających pomocy w zakresie dożywiania, konieczności rozwoju bazy żywieniowej i dowozu posiłków, jak również sytuacji finansowej gminy.

Udział Gminy Miasto Szczecin w realizacji Programu oraz pomiar efektów wydatkowania środków prezentuje tabela 4.

Analiza realizacji zadania wskazuje na spełnienie przez gminę kryterium finansowania Programu ze środków własnych w latach 2011-2017 na poziomie od 27,7\% do $52,3 \%$ poniesionych na ten cel wydatków.

$\mathrm{Na}$ podstawie rozporządzenia Rady Ministrów w sprawie realizacji wielolet- 
Tabela 4. Środki finansowe oraz wybrane mierniki efektów wydatkowania środków publicznych w latach 2011-2017 w budżecie państwa i w mieście Szczecin dla programu „Pomoc państwa w zakresie dożywiania”

\begin{tabular}{|c|c|c|c|c|c|c|c|c|c|c|c|c|c|c|c|c|c|c|c|c|}
\hline \multirow{2}{*}{ Lp. } & \multirow{2}{*}{\begin{tabular}{|c|} 
Program \\
rządowy /Zadanie \\
samorządowo-rządowe
\end{tabular}} & \multicolumn{3}{|c|}{2011 rok } & \multicolumn{3}{|c|}{2012 rok } & \multicolumn{3}{|c|}{2013 rok } & \multicolumn{3}{|c|}{2014 rok } & \multicolumn{3}{|c|}{2015 rok } & \multicolumn{3}{|c|}{2016 rok } & \multirow{2}{*}{\begin{tabular}{|c|}
2017 rok \\
$\begin{array}{c}\text { Plan } \\
\text { (w tys. zt) }\end{array}$
\end{tabular}} \\
\hline & & $\begin{array}{c}\text { Plan } \\
\text { (w tys. zt) }\end{array}$ & $\begin{array}{c}\text { Wykon. } \\
\text { (w tys. zl) }\end{array}$ & Wyk. \% & $\left|\begin{array}{c}\text { Plan } \\
\text { (w tys. zt) }\end{array}\right|$ & $\left|\begin{array}{c}\text { Wykon. } \\
\text { (w tys. zit }\end{array}\right|$ & Wyk. \% & \begin{tabular}{|c|} 
Plan \\
(w tys. \\
zt)
\end{tabular} & \begin{tabular}{|c|} 
Wykon. \\
(w tys. \\
zf)
\end{tabular} & Wyk. \% & $\begin{array}{c}\text { Plan } \\
\text { (w tys. } \\
\text { zl) }\end{array}$ & \begin{tabular}{|c} 
Wykon. \\
(w tys. \\
zi)
\end{tabular} & Wyk. \% & $\begin{array}{c}\text { Plan } \\
\text { (w tys. } \\
\text { zt) }\end{array}$ & \begin{tabular}{|c|} 
Wykon. \\
(w tys. \\
zf)
\end{tabular} & Wyk. \% & $\begin{array}{c}\text { Plan } \\
\text { (w tys. } \\
\text { zf) }\end{array}$ & \begin{tabular}{|c} 
Wykon. \\
(w tys. \\
zt)
\end{tabular} & Wyk. \% & \\
\hline \multirow[t]{6}{*}{1.} & BUDŻET PAŃSTWA & & & & & & & & & & & & & & & & & & & \\
\hline & \multicolumn{4}{|c|}{$\begin{array}{l}\text { Funkcja 13. Zabezpieczenie społeczne i wspieranie } \\
\text { rodziny }\end{array}$} & & & & & & & & & & & & & & & & \\
\hline & \multicolumn{5}{|c|}{ Program wieloletni „Pomoc państwa w zakresie dożywiania” } & & & & & & & & & & & & & & & \\
\hline & $\begin{array}{l}\text { Wydatki budżetu } \\
\text { państwa - } \\
\text { Wojewodowie } \\
\text { - część } 85\end{array}$ & 551749 & 547597 & $99,2 \%$ & 553245 & 549081 & $99,2 \%$ & 555130 & 553331 & $99,7 \%$ & 550000 & 542172 & $98,6 \%$ & 550000 & 543646 & $98,8 \%$ & 549995 & 516628 & $93,9 \%$ & 550000 \\
\hline & Mierniki: & & & & & & & & & & & & & & & & & & & \\
\hline & $\begin{array}{l}\text { - liczba osób objętych } \\
\text { dożywianiem } \\
\text { - w mln }\end{array}$ & 2,0 & 1,9 & $96,7 \%$ & 2,0 & 1,9 & $95,0 \%$ & 1,8 & 1,9 & $105,6 \%$ & 2,0 & 1,8 & $90,0 \%$ & 2,0 & 1,7 & $85,0 \%$ & 1,8 & 1,5 & $84,4 \%$ & 1,8 \\
\hline \multirow[t]{7}{*}{2.} & $\begin{array}{l}\text { BUDŻET MIASTA } \\
\text { SZCZECIN }\end{array}$ & & & & & & & & & & & & & & & & & & & \\
\hline & \multicolumn{3}{|c|}{ Sfera: Pomoc społeczna i ochrona zdrowia } & & & & & & & & & & & & & & & & & \\
\hline & \multicolumn{2}{|l|}{$\begin{array}{l}\text { Program positek dla } \\
\text { potrzebujących }\end{array}$} & & & & & & & & & & & & & & & & & & \\
\hline & $\begin{array}{l}\text { Wydatki na realizację } \\
\text { zadania }\end{array}$ & 6043 & 5952 & $98,5 \%$ & 6383 & 5762 & $90,3 \%$ & 5962 & 5774 & $96,9 \%$ & 6559 & 6493 & $99,0 \%$ & 6678 & 6524 & $97,7 \%$ & 8122 & 5941 & $73,1 \%$ & 7495 \\
\hline & - z środków własnych & 2272 & 2238 & $98,5 \%$ & 2830 & 2209 & $78,1 \%$ & 2522 & 2337 & $92,7 \%$ & 3021 & 2954 & $97,8 \%$ & 3145 & 2991 & $95,1 \%$ & 3808 & 1648 & $43,3 \%$ & 3917 \\
\hline & $\begin{array}{l}\text { - z dotacji celowej } \\
\text { z budżetu państwa }\end{array}$ & 3771 & 3715 & $98,5 \%$ & 3554 & 3554 & $100,0 \%$ & 3440 & 3437 & $99,9 \%$ & 3538 & 3538 & $100,0 \%$ & 3533 & 3533 & $100,0 \%$ & 4314 & 4293 & $99,5 \%$ & 3578 \\
\hline & $\begin{array}{l}\text { Udział środków } \\
\text { własnych na realizację } \\
\text { Programu }\end{array}$ & $37,6 \%$ & $37,6 \%$ & $100,0 \%$ & $44,3 \%$ & $38,3 \%$ & $86,5 \%$ & $42,3 \%$ & $40,5 \%$ & $95,7 \%$ & $46,1 \%$ & $45,5 \%$ & $98,8 \%$ & $47,1 \%$ & $45,9 \%$ & $97,4 \%$ & $46,9 \%$ & $27,7 \%$ & $59,2 \%$ & $52,3 \%$ \\
\hline
\end{tabular}




\begin{tabular}{|c|c|c|c|c|c|c|c|c|c|c|c|c|c|c|c|c|c|c|c|}
\hline $\begin{array}{l}\text { Udział dotacji na } \\
\text { realizację Programu }\end{array}$ & $62,4 \%$ & $62,4 \%$ & $\mid 100,0 \%$ & $55,7 \%$ & $61,7 \%$ & $110,8 \%$ & $57,7 \%$ & $59,5 \%$ & $103,2 \%$ & $53,9 \%$ & $54,5 \%$ & $101,0 \%$ & $52,9 \%$ & $54,1 \%$ & $102,4 \%$ & $53,1 \%$ & $72,3 \%$ & $136,1 \%$ & $47,7 \%$ \\
\hline \multicolumn{20}{|l|}{ Mierniki: } \\
\hline - liczba uczestników & & & & & & & 828 & 707 & $85,4 \%$ & 828 & 712 & $86,0 \%$ & & & & & & & \\
\hline $\begin{array}{l}\text { - liczba dorosłych } \\
\text { korzystajacych } \\
\text { z dożywiania } \\
\text { w ramach programu }\end{array}$ & & & & & & & & & & & & & 5759 & 5650 & $98,1 \%$ & 6200 & 6170 & $99,5 \%$ & 5759 \\
\hline $\begin{array}{l}\text { - liczba dzieci } \\
\text { korzystajacych } \\
\text { z dożywiania } \\
\text { w ramach programu }\end{array}$ & & & & & & & & & & & & & 3000 & 3000 & $100,0 \%$ & 4000 & 3834 & $95,9 \%$ & 3000 \\
\hline $\begin{array}{l}\text { - liczba osób } \\
\text { korzystajacych } \\
\text { z programu „,Goracy } \\
\text { positek dla seniora” }\end{array}$ & & & & & & & & & & & & & 155 & 155 & $100,0 \%$ & 55 & 55 & $100,0 \%$ & 55 \\
\hline $\begin{array}{l}\text { - średni koszt jednego } \\
\text { positku }\end{array}$ & & & & $5,40 \mathrm{zt}$ & $5,40 \mathrm{zt}$ & $100,0 \%$ & $5,70 \mathrm{zt}$ & $6,00 \mathrm{zt}$ & $105,3 \%$ & $6,00 \mathrm{zt}$ & $6,00 \mathrm{zt}$ & $100,0 \%$ & $6,10 \mathrm{zt}$ & $6,10 \mathrm{zt}$ & $100,0 \%$ & $6,10 \mathrm{zt}$ & $6,10 \mathrm{zt}$ & $100,0 \%$ & $6,10 \mathrm{zf}$ \\
\hline $\begin{array}{l}\text { - liczba osób } \\
\text { korzystających } \\
\text { z dożywiania } \\
\text { w stosunku do liczby } \\
\text { mieszkańców }\end{array}$ & & & & $0,7 \%$ & $0,7 \%$ & $100,0 \%$ & & & & & & & & & & & & & \\
\hline $\begin{array}{l}\text { - liczba osób } \\
\text { korzystajacych } \\
\text { z dożywiania } \\
\text { w stosunku do liczby } \\
\text { osób korzystających } \\
\text { z pomocy społecznej }\end{array}$ & & & & $11,4 \%$ & $11,4 \%$ & $100,0 \%$ & & & & & & & & & & & & & \\
\hline $\begin{array}{l}\text { - średni koszt zadania } \\
\text { na } 1 \text { mieszkańca }\end{array}$ & $14,88 \mathrm{zt}$ & $14,66 \mathrm{zt}$ & $98,5 \%$ & & & & $14,58 \mathrm{zt}$ & $14,12 \mathrm{zt}$ & $96,8 \%$ & $16,08 \mathrm{zt}$ & $15,91 \mathrm{zt}$ & $98,9 \%$ & $16,41 \mathrm{zt}$ & $16,03 \mathrm{zt}$ & $97,7 \%$ & & & & \\
\hline
\end{tabular}

Źródło: opracowanie własne na podstawie sprawozdań rocznych z wykonania budżetu państwa i budżetu miasta 
Tabela 5. Pomiar efektów wydatkowania środków publicznych w latach 2011-2013 z realizacji

\begin{tabular}{|c|c|c|c|c|}
\hline \multirow[t]{2}{*}{ Lp. } & \multirow[t]{2}{*}{ Wyszczególnienie } & \multicolumn{3}{|c|}{ Ogółem, w tym } \\
\hline & & 2011 rok & 2012 rok & 2013 rok \\
\hline I. & Osoby korzystające z pomocy w ramach Programu & 1933998 & 1922675 & 1936217 \\
\hline II. & Działania programowe & & & \\
\hline 1. & Posiłek & & & \\
\hline \multirow[t]{5}{*}{ a/ } & Liczba osób, które skorzystały z pomocy w formie posiłku, w tym: & 886170 & 881668 & 905160 \\
\hline & - w formie całodziennego wyżywienia & 65437 & 69223 & 79583 \\
\hline & - w formie pełnego obiadu & 403862 & 402637 & 421215 \\
\hline & - w formie jednego gorącego dania & 337523 & 335987 & 339968 \\
\hline & - w formie mleka, bułki / kanapki & 67107 & 53031 & 46445 \\
\hline \multirow[t]{5}{*}{$\mathrm{b} /$} & Liczba wydanych posiłków (jako jedno świadczenie) & 111817775 & 117250360 & 121423461 \\
\hline & - w formie całodziennego wyżywienia & 6253839 & 6811909 & 7997338 \\
\hline & $-\mathrm{w}$ formie pełnego obiadu & 52364245 & 58591418 & 55973549 \\
\hline & - w formie jednego gorącego dania & 45480881 & 45530198 & 46347669 \\
\hline & - w formie mleka, bułki / kanapki & 7718810 & 6316835 & 5511758 \\
\hline c/ & Wydatki przeznaczone na pomoc $\mathrm{w}$ formie posiłku - w tys. zł & $427565 \mathrm{zl}$ & $462713 \mathrm{zl}$ & $492979 \mathrm{zl}$ \\
\hline $\mathrm{d} /$ & Średni koszt jednego posiłku dla osób korzystających z pomocy w ramach Programu & $3,82 \mathrm{zł}$ & $3,95 \mathrm{zl}$ & $4,06 \mathrm{zł}$ \\
\hline 2. & Zasiłek celowy na zakup posiłku lub żywności & & & \\
\hline a/ & Liczba osób, które skorzystały z pomocy w formie zasiłku celowego & 1254320 & 1259025 & 1255213 \\
\hline $\mathrm{b} /$ & Liczba świadczeń & 2353363 & 2333495 & 2360779 \\
\hline c/ & Wydatki przeznaczone na pomoc w formie zasiłku celowego - w tys. zł & $342411 \mathrm{zl}$ & $335436 \mathrm{zl}$ & $330352 \mathrm{zl}$ \\
\hline $\mathrm{d} /$ & Średni koszt jednego świadczenia w formie zasiłku celowego w ramach Programu* & $145 \mathrm{zł}$ & $144 \mathrm{zl}$ & $140 \mathrm{zl}$ \\
\hline 3. & Świadczenie rzeczowe w postaci produktów żywnościowych & & & \\
\hline a/ & Liczba osób, które skorzystały z pomocy w formie świadczenia rzeczowego & 105235 & 96527 & 87679 \\
\hline b/ & Wydatki przeznaczone na pomoc w formie świadczenia rzeczowego - w tys. zł & $10916 \mathrm{zl}$ & $9754 \mathrm{zł}$ & $9503 \mathrm{zl}$ \\
\hline c/ & Średni koszt świadczenia rzeczowego na jedną osobę* & $104 \mathrm{zl}$ & $101 \mathrm{zl}$ & $108 \mathrm{zl}$ \\
\hline 4. & Dowóz posiłków & & & \\
\hline \multirow[t]{3}{*}{ a/ } & Liczba osób, którym zorganizowano dowóz posiłków & 62174 & 64564 & 63799 \\
\hline & - zorganizowano dowóz posiłków & 61721 & 64564 & 63593 \\
\hline & - dowieziono produkty żywnościowe do przygotowania posiłków & 453 & & 206 \\
\hline $\mathrm{b} /$ & Wydatki przeznaczone na realizację dowozu - w tys. zł & $9311 \mathrm{zl}$ & $9880 \mathrm{zl}$ & $9984 \mathrm{zl}$ \\
\hline c/ & Średni koszt dowozu posiłku na jedną osobę* & $150 \mathrm{zl}$ & $153 \mathrm{zl}$ & $156 \mathrm{zl}$ \\
\hline 5. & Baza żywieniowa & & & \\
\hline \multirow[t]{3}{*}{ a/ } & Liczba punktów żywieniowych & 22223 & 22196 & 22195 \\
\hline & - stołówki & 14109 & 13807 & 13834 \\
\hline & - pomieszczenia do przygotowywania i wydawania posiłków & 8114 & 8389 & 8361 \\
\hline \multirow[t]{3}{*}{$\mathrm{b} /$} & Liczba uruchomionych punktów żywieniowych & 144 & 136 & 132 \\
\hline & - stołówki & 73 & 74 & 65 \\
\hline & - pomieszczenia do przygotowywania i wydawania posiłków & 71 & 62 & 67 \\
\hline
\end{tabular}

* wskaźniki dodane przez autora

Źródło: opracowanie własne na podstawie Uchwał Rady Ministrów w sprawie przyjęcia sprawozdania 
programu wieloletniego „Pomoc państwa w zakresie dożywiania”

\begin{tabular}{|c|c|c|c|c|c|c|c|c|}
\hline \multicolumn{3}{|c|}{ dzieci do 7 roku życia } & \multicolumn{3}{|c|}{$\begin{array}{l}\text { uczniowie do czasu ukończenia } \\
\text { szkoły ponadgimnazjalnej }\end{array}$} & \multicolumn{3}{|c|}{$\begin{array}{l}\text { osoby i rodziny znajdujace się } \\
\text { w sytuacjach wymienionych w art. } 7 \\
\text { ustawy o pomocy społecznej }\end{array}$} \\
\hline 2011 rok & 2012 rok & 2013 rok & 2011 rok & 2012 rok & 2013 rok & 2011 rok & 2012 rok & 2013 rok \\
\hline 301232 & 310232 & 322679 & 730122 & 755561 & 684149 & 886948 & 893609 & 901611 \\
\hline & & & & & & & & \\
\hline & & & & & & & & \\
\hline & & & & & & & & \\
\hline & & & & & & & & \\
\hline & & & & & & & & \\
\hline 15485721 & 17660384 & 20014820 & 80482060 & 83092907 & 78247048 & 15849994 & 16497069 & 17568446 \\
\hline 4718512 & & & 1335030 & & & 200297 & & \\
\hline 4907404 & & & 38639889 & & & 8816952 & & \\
\hline 4877226 & & & 33815152 & & & 6788503 & & \\
\hline 982579 & & & 6691989 & & & 44242 & & \\
\hline $3,81 \mathrm{zt}$ & $3,90 \mathrm{zf}$ & $4,02 \mathrm{zl}$ & $3,50 \mathrm{zl}$ & $3,33 \mathrm{zl}$ & $3,80 \mathrm{zl}$ & $5,48 \mathrm{zl}$ & $5,40 \mathrm{zl}$ & $5,32 \mathrm{zl}$ \\
\hline & & & & & & & & \\
\hline & & & & & & & & \\
\hline & & & & & & & & \\
\hline & & & & & & & & \\
\hline & & & & & & & & \\
\hline 16649 & 16289 & 14609 & 28705 & 26200 & 23399 & 60218 & 54303 & 49863 \\
\hline & & & & & & & & \\
\hline & & & & & & & & \\
\hline & & & & & & & & \\
\hline & & & & & & & & \\
\hline & & & & & & & & \\
\hline & & & & & & & & \\
\hline & & & & & & & & \\
\hline & & & & & & & & \\
\hline & & & & & & & & \\
\hline & & & & & & & & \\
\hline & & & & & & & & \\
\hline & & & & & & & & \\
\hline & & & & & & & & \\
\hline & & & & & & & & \\
\hline & & & & & & & & \\
\hline
\end{tabular}

z realizacji programu wieloletniego „Pomoc państwa w zakresie dożywiania” za lata 2011, $2012,2013$.

Wydział Zarządzania UW ～DOI 10.7172/1733-9758.2017.25.9 
niego programu „Pomoc państwa w zakresie dożywiania określone zostały dane niezbędne do monitorowania realizacji Programu oraz system sprawozdawczy. Zawiera on dane odnoszące się zarówno do odbiorców Programu jak i form udzielanej pomocy w ramach Programu - por. tabela 5.

W tabeli 5 wyróżniono następujące rodzaje mierników efektów i mierniki kosztowe, które charakteryzują efektywność programu rządowego:

1. Mierniki produktów: liczba osób korzystających $\mathrm{z}$ pomocy $\mathrm{w}$ ramach Programu; liczba osób, które skorzystały z pomocy w formie posiłku; liczba wydanych posiłków; liczba osób, które skorzystały w formie zasiłku celowego w ramach Programu; liczba świadczeń; liczba osób, które skorzystały z pomocy w formie świadczenia rzeczowego; liczba osób, którym zorganizowano dowóz posiłków; liczba punktów żywieniowych, liczba uruchomionych punktów żywieniowych, liczba gmin uczestniczących w Programie ogółem (2479), z uwzględnieniem podziału na województwa i udział środków własnych w ogólnej kwocie na dożywianie.

2. Mierniki kosztowe: udział środków własnych i dotacji w całkowitym koszcie Programu; wydatki przeznaczone na pomoc w formie: posiłku, zasiłku celowego, świadczenia rzeczowego, dowozu.

3. Mierniki efektywności: średni koszt jednego posiłku dla osób korzystających $\mathrm{z}$ pomocy $\mathrm{w}$ ramach Programu, średni koszt jednego świadczenia $\mathrm{w}$ formie zasiłku celowego, średni koszt świadczenia rzeczowego na jedna osobę, średni koszt dowozu posiłku na jedną osobę.

W mieście Szczecin można wskazać na istnienie następujących wartości mierników:

- udział środków własnych i dotacji w całkowitym koszcie Programu wyniósł odpowiednio $37,4 \%$ i $62,6 \%$. Udzial środków własnych był wyższy o $2,4 \%$ w stosunku do ogólnych kosztów realizacji Programu państwa (35\%), natomiast w stosunku do województwa zachodniopomorskiego o $3,4 \%(34 \%)$;

- liczba osób korzystających z pomocy w ramach Programu - 11 434, co stanowi $1 \%$ osób objętych łączną pomocą w skali państwa (1 933 998);
- średni koszt jednego posiłku dla osób korzystających $\mathrm{z}$ pomocy $\mathrm{w}$ ramach Programu - ogółem wyniósł 4,59zł, przy średnim koszcie w skali państwa 3,82 zł;

- średni koszt świadczenia w formie zasiłku celowego wyniósł odpowiednio 113 zł, przy średnim koszcie w skali państwa $145 \mathrm{zl}$.

Dane zawarte w tabeli 5 mają wysoką rangę informacyjną $\mathrm{w}$ odniesieniu zarówno do kosztów przeznaczonych na program samorządowo-rządowy, jak i w odniesieniu do pomiaru efektów uzyskiwanych ze środków publicznych. Wskazują równocześnie na złożoność działania „Pomoc państwa w zakresie dożywiania”. Przedmiotem prac badawczych i analitycznych w rządzie i w samorządach winny być analizy benchmarkingowe dające bazę kosztowo-efektywnościową dla opracowywania standardów usług społecznych.

Istnieją możliwości koordynacji pomiaru efektów wydatkowania środków publicznych przez sektor rządowy i samorzadowy. Wymaga to dalszej pogłębionej analizy w ujęciu kosztowym, ilościowym i jakościowym.

\section{Podsumowanie}

Analiza poziomu adekwatności środków do realizacji zadań rządowych wskazuje na konieczność angażowania środków własnych przez miasta metropolitalne. Stopień ich dofinansowania uzależniony jest od poziomu niezbędnych potrzeb do prawidłowej ich realizacji oraz możliwości finansowych poszczególnych samorządów w kontekście realizacji zadań własnych. Niższy udział źródeł finansowania zadań rzadowych w miastach metropolitalnych wymusza wdrożenie zarządzania środkami publicznymi również w obszarze gospodarki nadwyżką lub deficytem, przekształcającym się w dług publiczny oraz konieczności wprowadzenia racjonalnego i efektywnego zarządzania środkami publicznymi.

Celowość i oszczędność wydatkowania środków publicznych określone zostały w ustawie o finansach publicznych. Wydatki publiczne powinny być dokonywane w sposób celowy i oszczedny, z zachowaniem zasady uzyskiwania najlepszych efektów z danych nakładów. Dlatego też w ostatnich latach transformacji sektora publicznego jego rozwojowy charakter ukierunko- 
wany jest na poprawę sprawności systemów dostarczania dóbr i usług publicznych, jako kluczowe wyzwanie w obszarze zarzadzania zadaniami publicznymi poprzez działania efektywnościowe, określane w literaturze jako nowe zarządzanie publiczne - New Public Management - NPM (Lubińska, 2009, s. 17).

Również w obszarze pomiaru efektów należałoby rozważyć możliwość ujednolicenia systemów monitorowania realizacji zadań, głównie zadań rządowych i samorządowo-rządowych, w tym programów rządowych (ujętych zarówno w wieloletnich programach budżetu państwa, jak i programach rządowych sektorowych realizowanych przez poszczególne ministerstwa, finansowanych w ramach rezerw celowych) i wykorzystania (lub stworzenia) w ramach dobrych praktyk jednolitych mierników pomiaru efektów z danych nakładów dla tych zadań. Pozwoli to na wykorzystanie zasad jawności, przejrzystości, skuteczności, efektywności oraz sprawności w ocenie gospodarowania środkami publicznymi przy zachowaniu porównywalności między jednostkami samorządu terytorialnego. Stanowiłoby to też punkt odniesienia dla tych jednostek w skali województwa czy państwa.

\section{Przypisy}

1 Monitor Polski, poz. 671.

2 Por. Wyrok Trybunału Konstytucyjnego z dnia 4 marca 2014 r., sygn. Akt K 13/11.

3 Ibidem, s. 71.

\section{Bibliografia}

Dębowska-Romanowska， T. (2014). Dylematy przekształceń ustroju finansów lokalnych. Finanse Komunalne, 1-2.

Franek, S., Będzieszak, M. i Lubinska, T. (2011) Budżet efektów samorządu terytorialnego (BEST) koncepcja i uwarunkowania. Zeszyty Naukowe nr 682, Ekonomiczne Problemy Ustug, 76, VII Forum Samorządowe, Uniwersytet Szczeciński.

Frączkiewicz-Wronka, A. (red.) (2007). Zarzadzanie publiczne $w$ lokalnej polityce spotecznej. Warszawa WSP TWP
Glumińska-Pawlic, J. (2014). Sesja „Samodzielność finansowa samorządu terytorialnego", konferencja w Jachrance 2013. Finanse Komunalne, 1-2.

Lubińska, T. (red.) (2011). Kierunki modernizacji zarzadzania $w$ jednostkach samorządu terytorialnego. Warszawa: Difin.

Lubińska, T. (red.) (2009). Nowe zarzadzanie publiczne - skuteczność i efektywność, Budżet zadaniowy $w$ Polsce. Warszawa: Difin.

Owsiak, S. (2005). Finanse publiczne. Teoria i praktyka. Warszawa: Wydawnictwo Naukowe PWN.

Sekuła, A. (2016). System subwencjonowania jednostek samorzadu terytorialnego w Polsce: dysfunkcje i pożadane kierunki racjonalizacji. Gdańsk: Politechnika Gdańska.

Wyrok Trybunału Konstytucyjnego z dnia 4 marca 2014 r., sygn. Akt K 13/11.

\section{Akty prawne}

Konstytucja Rzeczpospolitej Polskiej z dnia 2 kwietnia 1997 r., Dz.U. nr 78, poz.483.

Uchwała nr 221 z dnia 10 grudnia 2013 r. Rady Ministrów w sprawie ustanowienia wieloletniego programu wspierania finansowego gmin w zakresie dożywiania „Pomoc państwa w zakresie dożywiania" na lata 2014-2020, M.P. poz. 821.

Ustawa z dnia 13 listopada 2003 r. o dochodach jednostek samorzadu terytorialnego, tekst jednolity Dz.U. z 2017 r., poz. 2260 z późniejszymi zmianami.

Ustawa z dnia 8 marca 1990 r. o samorządzie gminnym, tekst jednolity Dz.U. z 2017 r., poz. 1875 z późniejszymi zmianami.

Ustawa z dnia 5 czerwca 1998 r. o samorzadzie powiatowym, tekst jednolity Dz.U. z 2017 r. poz. 1868 z późniejszymi zmianami.

Ustawa z dnia 5 czerwca 1998 r. o samorządzie województwa, tekst jednolity Dz.U. z 2017 r., poz. 2096 z późniejszymi zmianami.

Ustawa z dnia 27 sierpnia 2009 r. o finansach publicznych, tekst jednolity Dz.U. z 2017 r., poz. 2077 z późniejszymi zmianami.

Ustawa z dnia 29 grudnia 2005 r. o ustanowieniu programu wieloletniego „Pomoc państwa w zakresie dożywiania” (Dz.U. Nr 267, poz. 2259 z późniejszymi zmianami).

Rozporządzenie Rady Ministrów z dnia 7 lutego 2006 r. w sprawie realizacji programu wieloletniego „Pomoc państwa w zakresie dożywiania” (Dz.U. Nr 25, poz. 186 z późniejszymi zmianami). 